\title{
Faktor-Faktor yang Mempengaruhi Akses dan Pemanfaatan Arsip Statis bagi Masyarakat: Studi Kasus Dinas Perpustakaan dan Kearsipan Kota Yogyakarta
}

\author{
Silma Yudhanti \\ Sekolah Vokasi, Universitas Gadjah Mada
}

\begin{abstract}
This paper aims to describe several factors that given impact on archival access and reference services. This research was conducted at Dinas Perpustakaan dan Kearsipan Kota Yogyakarta. Archival access and reference services is one of the steps in managing archival documents which has been the main task of the regional archival agency. Archival access and reference services is one of significant factors in successful management of archives. Therefore, it is necessary to understand several factors that impacted on successfull of archival access and reference services, especially in Dinas Perpustakaan dan Kearsipan Kota Yogyakarta. Data was consisted of primary and secondary one. Primary data were collected by participatory observation and interviews with archivists and persons in charge of archival access in Dinas Perpustakaan dan Kearsipan Kota Yogyakarta. Secondary ones were collecting from library materials, both conventional and electronic. The data was processing by triangulation to get description of archival access and reference services along with the impacting factors. The conclusion of this study are archival access and reference services in Dinas Perpustakaan dan Kearsipan Kota Yogyakarta have been adapted with their policy standards. Several factors that giving significant impacts on successfully of archival access and reference services in Dinas Perpustakaan dan Kearsipan Kota Yogyakarta are professionalism of human resources, especially archivists, availability of facilities and infrastructures, also as well as the existence of guidelines for archival access and reference services.
\end{abstract}

\section{INTISARI}

Makalah ini bertujuan untuk mendeskripsikan beberapa faktor yang mempengaruhi prosedur akses dan pemanfaatan arsip statis bagi masyarakat. Penelitian kualitatif deskriptif dilakukan di Dinas Perpustakaan dan Kearsipan Kota Yogyakarta. Akses dan pemanfaatan arsip merupakan salah satu tahapan dalam pengelolaan arsip statis yang menjadi tugas utama lembaga kearsipan daerah. Akses dan pemanfaatan arsip menjadi ujung tombak utama keberhasilan pengelolaan arsip statis. Oleh sebab itu, perlu kiranya memahami faktor-faktor yang berpengaruh terhadap keberhasilan akses dan pemanfaatan arsip statis, khususnya di Dinas Perpustakaan dan Kearsipan Kota Yogyakarta. Data yang dikumpulkan berupa data primer dan sekunder. Data primer diperoleh melalui observasi partisipasi dan wawancara dengan arsiparis dan penanggung jawab kegiatan akses di Dinas Perpustakaan dan Kearsipan Kota Yogyakarta. Adapun data sekunder berasal dari bahan pustaka, baik konvensional maupun elektronik. Data kemudian diolah dengan pendekatan triangulasi data untuk memperoleh gambaran kegiatan akses dan pemanfaatan arsip statis beserta faktor-faktor yang mempengaruhi. Kesimpulan yang diperoleh dari studi ini adalah akses dan pemanfaatan arsip statis di Dinas Perpustakaan dan Kearsipan Kota Yogyakarta telah sesuai dengan standar kebijakan yang berlaku. Adapun faktor-faktor yang mempengaruhi keberhasilan akses dan pemanfaatan arsip statis di Dinas Perpustakaan dan Kearsipan Kota Yogyakarta antara lain: profesionalisme sumber daya manusia terutama arsiparis, ketersediaan sarana dan prasarana, serta keberadaan pedoman akses dan pemanfaatan arsip statis.
Submitted: $17 / 05 / 2020$

Received: 09/08/2020

*Correspondence:

Silma Yudhanti

silmayudhanti@mail.ugm.ac.id

KEYWORDS:

access

archivist

archives

reference service

KATA KUNCl:

akses

arsiparis

arsip statis

pemanfaatan arsip

CITE THIS ARTICLE:

Yudhanti, S. (2020).

Faktor-Faktor yang

Mempengaruhi Akses dan Pemanfaatan Arsip

Statis bagi Masyarakat Studi Kasus Dinas

Perpustakaan dan

Kearsipan Kota Yogyakarta

. Jurnal Diplomatika, 3

(2), 98-109. 


\section{PENDAHULUAN}

Yogyakarta telah menjadi destinasi yang semakin dikenal luas oleh masyarakat dunia. Beragam ikon wisata fenomenal Yogyakarta dominan berada di wilayah Kota Yogyakarta. Jalan Malioboro, Titik 0 KM, Monumen Tugu, Alun-Alun Kidul, Keraton, serta Wisata Air Taman Sari menjadi tempat yang selalu ramai dikunjungi oleh wisatawan. Dinamika sejarah Kota Yogyakarta dicatat dalam berbagai sumber, baik sumber primer maupun sumber sekunder. Sumber primer yang menjadi rujukan utama dalam memahami Kota Yogyakarta adalah arsip.

Arsip menjadi bukti eksistensi gerak masyarakat dari suatu peradaban. "Arsip merupakan dokumen (yang merekam informasi) baik yang berbentuk tunggal maupun kelompok (berjilid) dan dokumen tersebut merupakan hasil dari kegiatan suatu lembaga atau kantor baik pemerintah maupun swasta dan digunakan sebagai rujukan dan bukti sejarah masa lampau" (Kementerian Pendidikan dan Kebudayaan, 2013, 8). Peristiwa yang terjadi pada masa lampau dapat diketahui dengan adanya arsip. Arsip tercipta sebab adanya suatu kegiatan. Arsip tersebut kemudian harus dikelola sesuai standar dan prosedur kearsipan sehingga dapat dimanfaatkan oleh masyarakat secara luas. Musliichah $(2016,4)$ menyatakan bahwa arsip menjadi pusat memori kehidupan, identitas, serta jati diri manusia dan peradaban dalam kehidupan berbangsa dan bertanah air yang menjadi sumber kekuatan untuk membangun dan mempertahankan kehidupan.

Pengelolaan arsip di Indonesia didasarkan pada pendekatan siklus hidup arsip. Dalam pendekatan tersebut, arsip dikategorikan menjadi arsip dinamis (record) dan arsip statis (archives) (Amsyah, 2015,2). Arsip dinamis, menurut Soelistyo-Basuki, merupakan informasi yang terekam, baik dibuat maupun diterima, oleh organisasi dan/atau perseorangan, dari bukti pelaksanaan transaksi atau kegiatan atau tindakan (Basuki, 2004, 13). Arsip dinamis tersebut berupa informasi terkait tugas, strategi, kebijakan, dan aktivitas lainnya yang bersifat operasional maupun manajerial dari suatu organisasi. Adapun arsip statis adalah arsip yang dikelola dengan berbagai tujuan untuk saat ini dan masa yang akan datang karena memiliki nilai kesejarahan, mendokumentasikan identitas, dan kepentingan ilmiah secara berkelanjutan (Loo, Eberhard, \& Bettington, 2008,12). Adapun arsip yang menjadi objek kajian makalah ini berupa arsip statis.

Arsip statis menyampaikan informasi kepada generasi mendatang tentang segala hal yang terjadi pada masa sekarang (Loo, Eberhard \& Bettington, 2008, 12). Keberadaan arsip menjadi penting sebagai pengingat atas segala yang pernah terjadi di suatu peradaban masyarakat. Oleh sebab itu, arsip perlu dikelola sesuai dengan standar dan kebijakan yang berlaku. Apabila didasarkan perundang-undangan, kewenangan pengelolaan arsip statis ada pada lembaga kearsipan, termasuk lembaga kearsipan daerah, salah satunya, yaitu Dinas Perpustakaan dan Kearsipan (selanjutnya disebut Dispusip) Kota Yogyakarta sebagai lembaga kearsipan tingkat kabupaten/kota.

Peraturan Walikota Yogyakarta Nomor 86 Tahun 2016, Dispusip Kota Yogyakarta bertugas "melaksanakan urusan pemerintahan daerah berdasarkan asas otonomi dan tugas pembantuan di bidang kearsipan dan perpustakaan". Salah satu fungsi dari Dispusip Kota Yogyakarta adalah "pelaksanaan koordinasi penyelenggaraan urusan di bidang kearsipan dan perpustakaan" (Peraturan Walikota Yogyakarta Nomor 86 Tahun 2016, 2016). Koleksi utama Dispusip Kota Yogyakarta berupa khasanah arsip statis khususnya di Lingkungan Pemerintah Kota Yogyakarta. Arsip statis yang berada dalam pengelolaan Dispusip Kota Yogyakarta terdiri dari berbagai jenis dan format diantaranya arsip tekstual, arsip rekaman suara, arsip foto, arsip kartografi, gambar 
teknik, dan kearsitekturan. Khasanah arsip statis yang menjadi ikon Dispusip Kota Yogyakarta antara lain arsip mengenai Monumen Tugu dan arsip dari beberapa pasar tradisional di Kota Yogyakarta.

Pengelolaan arsip statis adalah serangkaian aktivitas yang dilaksanakan secara sistematis sebagai upaya melestarikan khasanah arsip bernilai kebuktian dan kesejarahan. Dalam konsep siklus hidup arsip, pengelolaan arsip statis terdiri dari empat tahapan utama, yaitu akuisisi arsip, pengolahan arsip statis, preservasi arsip, serta akses dan layanan arsip. Hal tersebut juga ditegaskan dalam perundangundangan bahwa: "Akuisisi arsip statis, pengolahan arsip statis, preservasi arsip statis, dan akses arsip statis merupakan beberapa tahapan dari pengelolaan arsip statis" (Undang Undang Nomor 43 Tahun 2009, 2009).

Makalah ini berfokus pada tahapan layanan dan akses arsip statis. Layanan dan akses arsip statis menjadi penting bagi masyarakat yang membutuhkan informasi seputar sejarah atau peristiwa yang pernah terjadi pada masa lalu, khususnya bagi peneliti atau mahasiswa. Kegiatan layanan itu sendiri merupakan implementasi dari konsep ketersediaan arsip yang menjadi tanggungjawab lembaga kearsipan (Holbert, $1977,2)$. Selain itu, layanan arsip juga merupakan upaya agar arsip yang telah dikelola dapat dimanfaatkan oleh masyarakat, khususnya mahasiswa dan peneliti. Dispusip Kota Yogyakarta memfasilitasi beberapa layanan arsip, diantaranya layanan restorasi arsip tekstual, layanan penerimaan kunjungan, layanan konsultasi, layanan alih media, dan layanan peminjaman arsip statis. Adapun konsep akses arsip, menurut Jeremy, Woodley, \& Kupke (dalam Bettington, 2008, 352), akses terhadap arsip terbagi dalam berbagai cara bergantung pada jenis dan kepemilikan arsip serta kebijakan atau pembatasan yang berlaku. Aspek-aspek tersebut sudah seharusnya dipatuhi oleh arsiparis sebagai pengelola arsip maupun pengguna yang mengakses arsip.

Keberhasilan pengelolaan arsip statis dapat diamati dari keterjangkauan suatu arsip untuk dilayankan kepada pengguna atau user. Arsiparis sebagai pengelola arsip haruslah dapat memenuhi kebutuhan pengguna dalam mengakses arsip. Kebutuhan tersebut juga berkaitan dengan kecepatan penelusuran informasi dalam arsip serta keutuhan arsip yang dibutuhkan oleh pengguna.

Penyelenggaraan layanan dan akses arsip statis oleh lembaga kearsipan harus berdasarkan standar dan prosedur pelayanan yang ditetapkan oleh Arsip Nasional Republik Indonesia. Selain itu, lembaga kearsipan juga perlu untuk memperhatikan faktor-faktor yang berdampak signifikan terhadap akses dan kegiatan layanan arsip statis. Berdasarkan latar belakang tersebut, penulis mengajukan pertanyaan penelitian yaitu;

1. Bagaimana prosedur akses arsip statis dan pemanfaatan arsip statis yang berjalan di Dinas Perpustakaan dan Kearsipan Kota Yogyakarta?

2. Faktor-faktor apa sajakah yang mempengaruhi keberhasilan akses dan pemanfaatan arsip statis di Dinas Perpustakaan dan Kearsipan Kota Yogyakarta?

\section{METODE PENELITIAN}

Makalah ini didasarkan pada hasil penelitian kualitatif deskriptif, yaitu mendeskripsikan kebijakan akses dan prosedur layanan di Dispusip Kota Yogyakarta, serta menguraikan faktor-faktor yang mempengaruhi keberhasilan akses dan kegiatan layanan arsip di Dispusip Kota Yogyakarta. Data yang berhasil diperoleh terdiri dari data primer dan data sekunder. Data primer berupa transkripsi wawancara, rekaman wawancara, catatan lapangan, dan dokumentasi kegiatan. Adapun data sekunder 
berwujud referensi bahan pustaka dalam wujud buku, Tugas Akhir, peraturan perundang-undangan, dan jurnal. Untuk mengumpulkan data tersebut, penulis menggunakan tiga metode, yaitu: wawancara terstruktur dan tidak terstruktur dengan narasumber arsiparis dan penanggung jawab bagian layanan arsip statis Dispusip Kota Yogyakarta; observasi partisipatif dengan mengamati kegiatan pemanfaatan arsip melalui layanan arsip statis di Dispusip Kota Yogyakarta; dan studi pustaka dengan menelusuri dan membaca bahan pustaka di beberapa perpustakaan. Data yang telah terkumpul kemudian diolah dengan pendekatan triangulasi data dengan tahapan: pengklasifikasian data dan pemberian koding, analisis teori, dan penulisan hasil analisis.

\section{HASIL DAN PEMBAHASAN}

\section{Akses Arsip Statis Di Dinas Perpustakaan dan Kearsipan Kota Yogyakarta}

Akses arsip statis adalah bagian pengelolaan arsip statis yang memberikan kemudahan masyarakat dalam pemanfaatan arsip statis. Jeremy, Woodley, \& Kupke (dalam Bettington, 2008, 351) memaknai akses arsip statis sebagai syarat dan ketentuan dari ketersediaan arsip yang dikelola oleh lembaga kearsipan untuk dimanfaatkan oleh pengguna. Selain itu, akses arsip juga diartikan sebagai wewenang atau izin untuk memanfaatkan arsip (Pugh, 1992,6). Prinsip mendasar akses menurut ketiganya menekankan pada keberadaan kebijakan untuk dapat memanfaatkan arsip statis. Meskipun secara prinsip akses arsip statis terbuka bagi publik, namun tetap memperhatikan batasan-batasan tertentu, diantaranya perihal pembatasan akses dalam periode tertentu. Menurut Holbert $(1977,3)$ akses harus diberikan kepada seluruh lembaga arsip yang dapat berkontribusi untuk membantu peneliti atau pengguna arsip, dengan pengecualian apabila arsip dinyatakan tertutup oleh kebijakan hukum atau pembatasan lainnya.

Adapun Undang Undang Nomor 43 Tahun 2009 tentang Kearsipan menguraikan definisi akses sebagai "ketersediaan arsip sebagai hasil dari kewenangan hukum dan otorisasi legal serta keberadaan sarana bantu untuk mempermudah penemuan dan pemanfaatan arsip". Pernyataan tersebut juga didukung oleh International Council On Archives melalui Committee On Best Practices and Standards Working Group On Access dalam Principles of Access to Archives bahwa akses arsip adalah ketersediaan arsip yang digunakan untuk konsultasi sebagai hasil dari kewenangan hukum dan adanya sarana bantu penemuan kembali arsip. Apabila merujuk pada definisi tersebut, maka lembaga kearsipan harus menyediakan sarana bantu penemuan kembali arsip untuk mempermudah arsiparis dan pengguna dalam penelusuran arsip. Selain itu, lembaga kearsipan juga harus mencermati status keterbukaan dan ketertutupan arsip berdasarkan kebijakan yang berlaku. Akses arsip dalam makalah ini merujuk pada definisi menurut Jeremy, Woodley, \& Kupke (dalam Bettington, 2008, 11), yaitu syarat dan ketentuan dari ketersediaan arsip oleh lembaga kearsipan untuk dipatuhi bersama, khususnya oleh pengguna yang akan mengakses arsip.

Akses arsip statis merupakan salah satu indikator keberhasilan pengelolaan arsip statis. Lembaga kearsipan wajib memastikan ketersediaan arsip statis sehingga dapat diakses oleh pengguna dengan cepat, tepat, dan lengkap. Pengguna dapat mengakses arsip statis dengan syarat dan ketentuan yang diberlakukan lembaga kearsipan. Secara umum, akses arsip statis berpedoman pada Principles of Access to Archives yang dirumuskan oleh International Council on Archives (ICA) sebagai berikut: 
1. The public has the right of access to archives of public bodies. Both public and private entities should open their archives to the greatest extent possible;

2. Institutions holding archives make known the existence of the archives, including the existence of closed materials, and disclose the existence of restrictions that affect access to the archives;

3. Institutions holding archives adopt a pro-active approach to access;

4. Institutions holding archives ensure that restrictions on access are clear and of stated duration, are based on pertinent legislation, acknowledge the right of privacy and respect the rights of owners of private materials;

5. Archives are made available on equal and fair terms;

6. Institutions holding archives ensure that victims of serious crimes under international law have access to archives that provide evidence needed to assert their human rights and to document violations of them, even if those archives are closed to the general public;

7. Users have the right to appeal a denial of access;

8. Institutions holding archives ensure that operational constraints do not prevent access to archives;

9. Archivists have access to all closed archives and perform necessary archival work on them;

10. Archivists participate in the decision-making process on access.

Akses arsip statis juga harus berpegang pada syarat dan ketentuan yang diterapkan di Dispusip Kota Yogyakarta. Ketentuan akses arsip statis di Dispusip Kota Yogyakarta adalah Peraturan Daerah Nomor 3 Tahun 2017 tentang Penyelenggaraan Kearsipan dan Peraturan Walikota Yogyakarta Nomor 75 Tahun 2017 tentang Pedoman Akses dan Layanan Arsip Statis. Berdasarkan kedua ketentuan tersebut, pihak yang memperoleh izin akses arsip statis yaitu pengguna yang memiliki hak dan syarat melaksanakan kewajiban dalam akses arsip statis. Adapun arsip yang dapat diakses, menurut kedua ketentuan tersebut antara lain: "arsip statis mengenai putusan badan peradilan, arsip statis mengenai ketetapan, peraturan, surat edaran, ataupun bentuk kebijakan lain, baik yang tidak berlaku mengikat maupun mengikat ke dalam ataupun keluar serta pertimbangan lembaga penegak hukum, arsip statis mengenai surat perintah penghentian penyidikan atau penuntutan, arsip statis mengenai rencana pengeluaran tahunan penegak hukum, arsip statis mengenai laporan hasil pengembalian uang hasil korupsi, dan arsip terbuka untuk umum."

Pada dasarnya, sifat arsip statis prinsipnya terbuka untuk publik (Undang Undang Nomor 43 Tahun 2009, 2009). Hal ini karena fungsi utama arsip statis sebagai referensi utama pengetahuan kesejarahan masyarakat. Meski demikian tidak semua arsip statis dapat diakses oleh masyarakat. Hal tersebut diatur dalam Undang Undang Nomor 43 Tahun 2009 tentang Kearsipan pasal 64 ayat 3 bahwa "akses arsip statis didasarkan pada sifat keterbukaan dan ketertutupan sesuai dengan ketentuan peraturan perundang-undangan". Penutupan akses arsip statis harus ditaati oleh lembaga kearsipan sebagai organisasi yang menyediakan akses. Pembatasan akses arsip statis juga mempertimbangkan permintaan dari pihak pencipta atau pihak yang memiliki arsip (Bettington, 2008, 352). Penentuan penutupan akses arsip statis di Dispusip Kota Yogyakarta juga didasarkan pada permintaan pencipta arsip sebelum dilaksanakan penyerahan arsip statis. Apabila instansi pencipta mensyaratkan suatu arsip statis 
ditutup, maka Dispusip Kota Yogyakarta harus patuh terhadap persyaratan tersebut. Arsiparis Dispusip Kota Yogyakarta harus mampu memberikan pemahaman kepada pengguna ketika pengguna terkait penutupan akses arsip statis tersebut. Apabila terdapat pengguna yang tetap akan mengakses arsip statis yang ditutup, maka pengguna harus mendapatkan izin resmi dari instansi pencipta. Arsiparis Dispusip Kota Yogyakarta juga dapat berkomunikasi terlebih dahulu dengan pejabat struktural.

Dinas Perpustakaan dan Kearsipan Kota Yogyakarta memberikan akses arsip statis ketika ada permintaan dari pengguna. Setiap pengguna dapat mengakses arsip statis, baik itu mahasiswa, peneliti, atau masyarakat umum, disertai dengan permohonan. Permohonan digunakan sebagai bukti pertanggungjawaban bagi arsiparis.

Selain ketentuan, akses arsip juga berkaitan erat dengan syarat pemanfaatan arsip statis. Syarat akses arsip statis adalah ketersediaan fasilitas penelusuran arsip. Fasilitas akses arsip statis di Dispusip Kota Yogyakarta tersedia dalam dua bentuk, manual dan elektronik. Akses arsip statis bentuk manual tersedia dalam daftar arsip statis dan inventaris arsip statis. Kedua sarana tersebut disimpan secara tersusun berdasarkan tahun pengolahan di lemari ruang layanan Dispusip Kota Yogyakarta.
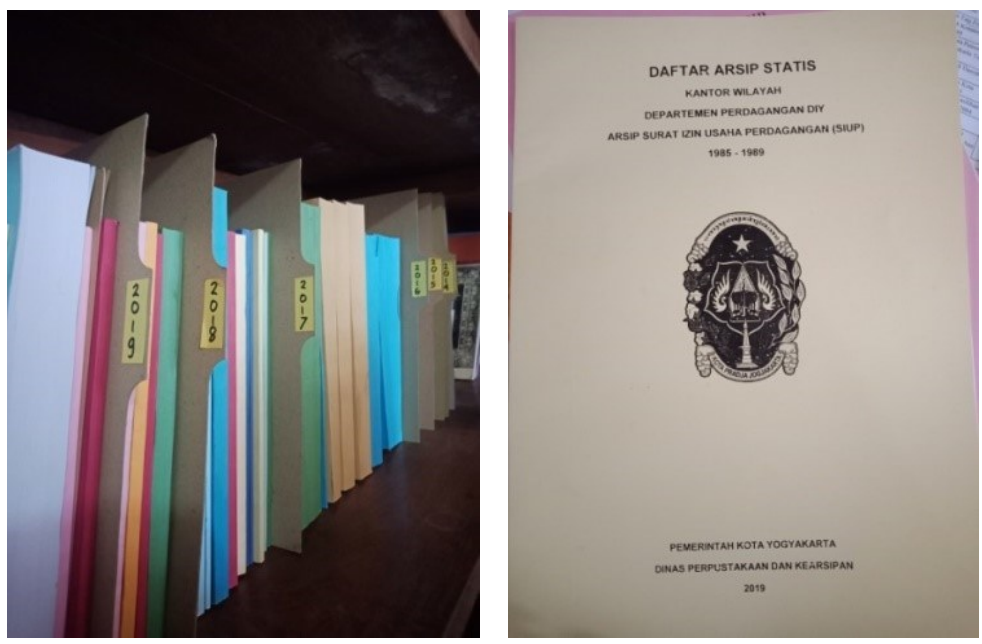

Gambar 1. Sarana Temu Kembali Konvensional

Sarana temu kembali arsip statis yang disusun Dinas Perpustakaan dan Kearsipan Kota Yogyakarta merupakan hasil pengolahan arsip pada tahun 2012 sampai tahun 2019. Sarana temu kembali tersebut, yaitu daftar arsip kartografi, kearsitekturan, dan gambar teknik, daftar arsip tekstual, inventaris arsip tekstual, daftar arsip foto, dan daftar arsip rekaman suara. Oleh karena perkembangan teknologi informasi, Dispusip Kota Yogyakarta juga menyediakan fasilitas sarana temu kembali arsip statis otomatis, yakni aplikasi Citra Arsip Foto Jogja Istimewa (CYNTIA) dan aplikasi Melacak Arsip Melalui Layar Kaca (MARISKA). Aplikasi CYNTIA dan MARISKA masing-masing telah memuat khazanah arsip foto sebesar 10.128 item yang siap diakses oleh pengguna. CYNTIA dan MARISKA mempunyai fungsi yang berbeda. CYNTIA diperuntukkan sebagai sarana temu kembali arsip foto, sedangkan MARISKA diperuntukkan sebagai sarana temu kembali arsip dalam berbagai bentuk dan media namun masih dalam tahap pengembangan sampai saat ini. Penambahan konten sedianya dilaksanakan tahun ini sesuai dengan rencana kerja yang telah ditetapkan pada awal tahun oleh Dispusip Kota Yogyakarta.

Berdasarkan wawancara dengan Sugeng Purnomo, A.Md., arsiparis penyelia Dispusip Kota Yogyakarta, menjelaskan bahwa CYNTIA telah berbasis online tetapi 
belum dapat diakses optimal oleh publik sebab sistem yang masih menyatu dengan OPAC Perpustakaan Kota Yogyakarta. Hal tersebut juga terjadi sebab keterbatasan server yang disediakan oleh Dinas Komunikasi Informatika dan Persandian Kota Yogyakarta. Adapun MARISKA adalah aplikasi internal berbasis offline yang hanya tersedia di komputer ruang layanan Dispusip Kota Yogyakarta.

Syarat berikutnya supaya arsip dapat diakses adalah ketersediaan arsip, secara fisik maupun informasi. Ketersediaan arsip merujuk pada format media rekam informasi, tema arsip statis, dan kondisi fisik arsip statis. Dinas Perpustakaan dan Kearsipan Kota Yogyakarta memiliki khazanah arsip statis berbagai bentuk dan media, antara lain: arsip foto, arsip kartografi, gambar teknik, dan kearsitekturan, serta arsip audio visual yang terdiri dari arsip audio/rekaman suara (kaset C60/C90), arsip audio video (kaset mikro, kaset mini DV, kaset Betamax, dan kaset VHS), arsip audio video media baru (CD/DVD, mini DVD), dan arsip film (pita roll film). Arsip bentuk khusus yang sudah dapat diakses oleh pengguna adalah arsip foto, arsip kartografi, kearsitekturan, dan gambar teknik, serta arsip rekaman suara. Sebagian lainnya belum dapat diakses lantaran keterbatasan alat pemutar arsip yang dimiliki oleh Dispusip Kota Yogyakarta untuk mengidentifikasi arsip tersebut. Arsip statis yang dilayankan kepada publik juga diklasifikasikan berdasarkan pencipta arsipnya diantaranya: arsip Sekretariat DPRD Kota Yogyakarta, arsip Kantor Pelayanan Pajak Daerah Kota Yogyakarta, arsip Dinas Perekonomian Kota Yogyakarta, arsip Badan Pembinaan Pendidikan Pelaksanaan Pedoman Penghayatan dan Pengamalan Pancasila (BP7) Daerah Tingkat II Yogyakarta, arsip Pasar Sentul, dan sebagainya.

Arsip statis yang dikelola oleh Dispusip Kota Yogyakarta disimpan di Depo Arsip Statis, kecuali arsip kartografi, kearsitekturan, dan gambar teknik yang disimpan di Depo Arsip Inaktif. Seluruh ruangan yang terdapat di Dispusip Kota Yogyakarta mempunyai penanggung jawab ruangan, termasuk Depo Arsip Statis. Hal tersebut dilakukan agar terdapat batasan akses bagi pihak yang tidak berkepentingan dalam mengakses arsip statis. Selain itu, pengamanan fisik tersebut juga sebagai upaya untuk melindungi fisik dan keutuhan informasi arsip statis. Adapun volume khazanah arsip statis yang terdapat di Depo Arsip Statis Dispusip Kota Yogyakarta:

Tabel 1. Volume arsip statis di Depo Arsip Statis

\begin{tabular}{lllll}
\hline No & Jenis Arsip & Jumlah & Tempat Simpan & Lokasi Simpan \\
\hline 1 & Arsip tekstual & $\begin{array}{l}30.318 \text { nomor } \\
\text { arsip }\end{array}$ & Roll'o Pack & Depo Arsip Statis \\
2 & Arsip Rekaman Suara & $\begin{array}{l}85 \text { kaset } \\
\text { Laci Arsip Rekaman }\end{array}$ & $\begin{array}{l}\text { Duara } \\
\text { Roll'o Pack }\end{array}$ & Depo Arsip Statis \\
4 & Arsip foto positif & 12.445 foto & Roll'o Pack & Depo Arsip Statis \\
\hline
\end{tabular}

\section{Pemanfaatan Arsip Statis Melalui Layanan Arsip Statis di Dinas Perpustakaan dan Kearsipan Kota Yogyakarta}

Layanan arsip merupakan kegiatan yang dilakukan oleh lembaga kearsipan untuk memenuhi kebutuhan pengguna atas informasi yang terekam dalam arsip. Dalam konteks administrasi publik, layanan arsip dikategorikan sebagai pelayanan publik. Pelayanan publik dapat diartikan sebagai suatu program pemerintah dalam menyediakan segala hal yang dibutuhkan masyarakat melalui fungsi public servant yaitu melayani kepentingan masyarakat sesuai dengan aturan yang berlaku (Ulum, 
2018, 7). Selain itu, menurut Undang Undang Nomor 25 Tahun 2009 tentang Pelayanan Publik Pasal 1 ayat 1 mendefinisikan bahwa:

"Pelayanan publik adalah kegiatan atau rangkaian kegiatan dalam rangka pemenuhan kebutuhan pelayanan sesuai dengan peraturan perundang-undangan bagi setiap warga negara dan penduduk atas barang, jasa, dan/atau pelayanan administratifyang disediakan oleh penyelenggara pelayanan publik"

Berdasarkan definisi tersebut, penyelenggara pelayanan publik harus menyelenggarakan layanan yang dibutuhkan oleh publik sesuai dengan tugas pokok dan fungsinya, termasuk lembaga kearsipan.

Kebutuhan masyarakat yang dilayani oleh lembaga kearsipan berupa layanan informasi yang terekam dalam arsip, terutama arsip statis. Menurut Jeremy, Woodley, dan Kupke (dalam Bettington, 2008, 361), layanan arsip mengarah pada kegiatan yang membantu orang untuk menggunakan arsip yang memiliki nilai guna untuk kepentingan penelitian. Lembaga kearsipan harus memberikan fasilitas kepada pengguna untuk menggunakan arsip secara mudah, cepat, tepat, dan lengkap. Layanan arsip juga diuraikan oleh Pugh $(1992,6)$ sebagai aktivitas yang dilakukan oleh arsiparis untuk mempertemukan antara pengguna dan arsip dalam memenuhi kebutuhan pengguna yang bersangkutan. Peranan arsiparis sangat dibutuhkan dalam kegiatan layanan arsip. Arsiparis merupakan orang yang secara langsung membantu pengguna dalam menyediakan arsip yang dibutuhkan.

Dalam konteks kebijakan, berdasarkan Lampiran Peraturan Kepala Arsip Nasional Republik Indonesia Nomor 28 Tahun 2011 tentang Pedoman Akses dan Layanan Arsip Statis layanan arsip statis dipahami sebagai "penyediaan arsip statis kepada pengguna arsip statis yang sah, termasuk penggandaan arsip statis sesuai dengan ketentuan peraturan perundang-undangan". Berdasarkan definisi tersebut, layanan arsip statis merupakan fasilitas yang disediakan lembaga kearsipan kepada masyarakat untuk memudahkan akses arsip sesuai dengan kebutuhan. Layanan arsip statis diberikan kepada pengguna arsip statis yang sah, telah memenuhi syarat dan ketentuan sesuai dengan peraturan yang berlaku.

Layanan arsip merupakan fasilitas penghubung antara pengguna dan lembaga kearsipan dalam mewujudkan kegiatan akses arsip. Dinas Perpustakaan dan Kearsipan Kota Yogyakarta memfasilitasi beberapa layanan arsip statis yang dapat dimanfaatkan oleh pengguna. Layanan arsip statis tersebut antara lain: layanan peminjaman arsip, layanan alih media, layanan konsultasi, layanan penerimaan kunjungan, dan layanan restorasi. Dinas Perpustakaan dan Kearsipan Kota Yogyakarta menyelenggarakan layanan arsip statis melalui serangkaian prosedur yang telah ditentukan. Prosedur tersebut harus dipatuhi oleh seluruh pihak yang terlibat, yakni arsiparis dan pengguna arsip. Adapun prosedur pelaksanaan layanan peminjaman arsip statis sebagaimana diatur dalam Peraturan Walikota Yogyakarta Nomor 75 Tahun 2017 tentang Pedoman Akses dan Layanan Arsip Statis dapat dicermati pada bagan alur berikut: 


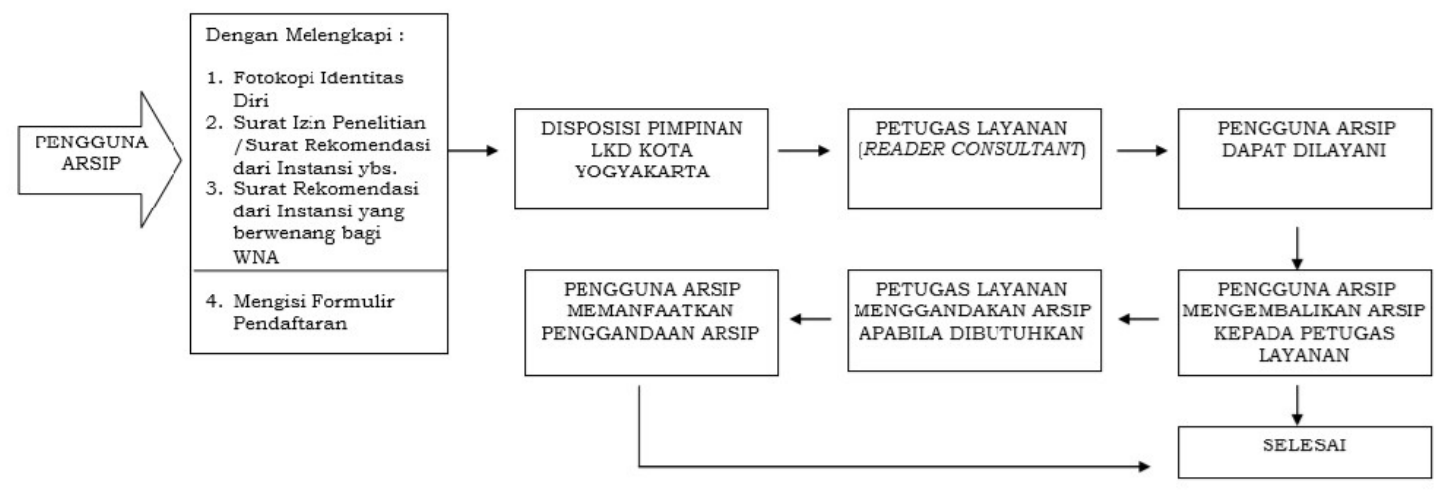

Gambar 2. Bagan prosedur layanan arsip statis di Dispusip Kota Yogyakarta

Bagan alur tersebut merupakan gambaran umum pelaksanaan layanan arsip statis di Dispusip Kota Yogyakarta. Penjelasan dari bagan prosedur layanan arsip statis di Dispusip Kota Yogyakarta:

1. Pengguna datang ke Dispusip Kota Yogyakarta dengan membawa persyaratan administratif berupa fotocopy identitas diri, surat izin penelitian/surat rekomendasi dari instansi yang bersangkutan, atau surat rekomendasi dari instansi berwenang bagi Warga Negara Asing. Dalam hal pengguna tidak membawa persyaratan tersebut maka pengguna tetap dapat mengakses arsip dengan mengisi formulir pendaftaran dan buku tamu.

2. Setelah memperoleh izin berupa disposisi dari pimpinan Dispusip Kota Yogyakarta, kluster layanan arsip dapat langsung melayani pengguna arsip.

3. Pengguna bertemu dengan petugas layanan atau arsiparis untuk berkonsultasi terkait arsip yang dibutuhkan.

4. Pengguna mengembalikan arsip kepada petugas layanan setelah selesai digunakan.

Pengguna dapat menggandakan arsip yang dibutuhkan melalui layanan reproduksi atau penggandaan arsip. Penggandaan arsip dilakukan oleh Dispusip Kota Yogyakarta dengan cara fotocopy atau alih media arsip. Penggandaan arsip dapat diminta oleh pengguna kepada arsiparis melalui tahapan berikut ini:

1. Pengguna menyampaikan permintaan penggandaan arsip kepada arsiparis bagian layanan untuk kemudian ditindaklanjuti.

2. Pengguna mengisi formulir permohonan penggandaan arsip.

3. Arsip yang telah digandakan dapat dimanfaatkan oleh pengguna.

Jika pengguna membutuhkan layanan penggandaan arsip maka dibebankan biaya sebesar biaya yang dikeluarkan oleh Dispusip Kota Yogyakarta untuk melakukan penggandaan arsip diluar kantor. Penggandaan arsip yang dapat dilakukan di kantor Dispusip Kota Yogyakarta hanya penggandaan arsip tekstual dengan ukuran kertas A4/ F4 melalui metode scan atau alih media arsip.

Selain berpedoman kepada Peraturan Walikota Yogyakarta Nomor 75 Tahun 2017, pelaksanaan layanan arsip statis di Dispusip Kota Yogyakarta juga diatur dalam Standar Operasional Prosedur (SOP). Berdasarkan SOP tersebut, waktu penyelesaian layanan peminjaman arsip dilakukan dalam kurun waktu 75 menit dengan pelaksana kegiatan layanan adalah arsiparis. 


\section{Faktor-Faktor yang Mempengaruhi Keberhasilan Akses dan Pemanfaatan Arsip Statis di Dinas Perpustakaan dan Kearsipan Kota Yogyakarta}

\section{Arsiparis}

Arsiparis memiliki peran penting dalam kegiatan layanan arsip. Namun secara umum, layanan arsip di Dispusip Kota Yogyakarta melibatkan seluruh pegawai baik itu arsiparis maupun pejabat struktural. Layanan konsultasi dan peminjaman dapat dilakukan oleh kepala bidang, kepala seksi, arsiparis, tenaga teknis, tenaga bantuan, serta analis data \& informasi. Arsiparis di Dispusip Kota Yogyakarta berjumlah 13 orang, terdiri dari 2 arsiparis ahli madya, 2 arsiparis ahli muda, 1 arsiparis mahir, dan selebihnya adalah arsiparis penyelia. Setiap arsiparis memiliki kesempatan untuk meningkatkan kompetensi, terutama melalui diklat maupun workshop lainnya. Selain itu, arsiparis sudah seharusnya memiliki literasi digital dan komunikasi antar personal.

Berkaitan dengan beban kerja, waktu operasional layanan arsip di Dispusip Kota Yogyakarta dibagi ke dalam 5 hari kerja dari hari Senin-Jumat. Adapun pembagian petugas diatur sebagai berikut: hari Senin dan Jumat terdapat 3-4 orang yang bertugas, sedangkan hari Selasa, Rabu, dan Kamis terdapat 6 orang yang bertugas. Perbedaan jumlah personil yang bertugas tersebut dilakukan untuk mengantisipasi layanan penerimaan kunjungan yang dijadwalkan pada hari Selasa, Rabu, dan Kamis oleh Bagian Protokol Pemerintah Kota Yogyakarta.

\section{Sarana dan Prasarana}

Layanan arsip dapat berjalan sesuai prosedur apabila tersedia sarana dan prasarana yang menunjang pelaksanaannya. Dinas Perpustakaan dan Kearsipan Kota Yogyakarta menyediakan beberapa sarana dan prasarana dalam menunjang pelaksanaan kegiatan layanan arsip. Adapun sarana dan prasarana layanan arsip meliputi:

a. Ruang baca layanan, terletak di bagian depan kantor Kluster Kearsipan Ngampilan, dan digunakan sebagai tempat berlangsungnya kegiatan layanan. Pengguna dapat membaca arsip dan berkonsultasi dengan petugas layanan di ruangan tersebut. Ruang layanan adalah satu-satunya ruangan yang dapat diakses oleh pengguna di Dispusip Kota Yogyakarta terkait dengan kegiatan layanan arsip.

b. Loker penitipan barang, yaitu fasilitas yang dapat digunakan oleh pengguna untuk menyimpan barang bawaan. Pengguna harus meletakkan barang bawaannya termasuk tas di dalam loker penitipan barang. Hal tersebut menjadi salah satu tata tertib yang harus dipatuhi oleh pengguna di ruang layanan. Pengguna harus dipastikan tidak membawa barang yang dapat merusak fisik dan isi informasi dari arsip.

c. Formulir layanan, terdiri dari formulir layanan peminjaman arsip statis, formulir surat izin penggandaan arsip, dan formulir peminjaman arsip media baru. Ketiga formulir tersebut juga menjadi syarat pengganti, khususnya bagi masyarakat umum, yang tidak memiliki surat pengantar dari institusi resmi. Pengguna wajib mengisi formulir tersebut sebagai bukti pertanggungjawaban untuk arsiparis yang melaksanakan tugas layanan arsip.

d. Buku layanan, adalah buku yang harus diisi oleh pengguna yang memanfaatkan arsip, digunakan sebagai syarat minimal pengguna ketika tidak membawa persyaratan administrasi.

e. Buku referensi, adalah bahan pustaka yang menjadi koleksi Dispusip Kota Yogyakarta dari kegiatan penelusuran arsip, antara lain: biografi tokoh, 
catatan perjalanan Pemerintah Kota Yogyakarta, dan buku yang terkait dengan makanan tradisional.

\section{KESIMPULAN}

Akses dan pemanfaatan arsip statis di Dispusip Kota Yogyakarta diselenggarakan dengan memperhatikan syarat dan ketentuan. Ketentuan akses arsip pada Dispusip Kota Yogyakarta merujuk Peraturan Daerah Nomor 3 Tahun 2017 tentang Penyelenggaraan Kearsipan dan Peraturan Walikota Yogyakarta Nomor 75 Tahun 2017 tentang Pedoman Akses dan Layanan Arsip Statis. Berdasarkan kebijakan tersebut, yang diizinkan mengakses arsip statis yaitu pengguna yang telah memenuhi syarat administratif yang diberlakukan di Dispusip Kota Yogyakarta. Adapun arsip yang dapat diakses diantaranya arsip statis mengenai putusan badan peradilan, arsip statis mengenai ketetapan, peraturan, surat edaran, ataupun bentuk kebijakan lain, dan sebagainya. Syarat akses arsip statis merujuk pada ketersediaan fasilitas penelusuran arsip dan ketersediaan arsip itu sendiri. Dispusip Kota Yogyakarta mempunyai fasilitas penelusuran arsip dalam bentuk manual melalui daftar arsip statis dan inventaris arsip serta bentuk elektronik melalui aplikasi Citra Arsip Foto Jogja Istimewa (CYNTIA) dan Melacak Arsip Melalui Layar Kaca (MARISKA). Dispusip Kota Yogyakarta mengelola arsip statis dalam berbagai bentuk dan media. Selain itu, arsip statis yang dapat diakses juga dikategorikan berdasarkan pencipta arsip dari instansi di lingkungan pemerintah Kota Yogyakarta.

Dinas Perpustakaan dan Kearsipan Kota Yogyakarta menyediakan layanan peminjaman arsip, layanan konsultasi, dan reproduksi arsip. Penyelenggaraan layanan arsip statis di Dispusip Kota Yogyakarta melalui prosedur dalam Peraturan Walikota Yogyakarta Nomor 75 Tahun 2017 dengan beberapa tahapan diantaranya pengguna arsip datang ke Dispusip Kota Yogyakarta dengan melengkapi persyaratan administrasi, setelah didisposisi oleh pimpinan Dispusip Kota Yogyakarta, pengguna bertemu dengan petugas layanan untuk konsultasi arsip yang dibutuhkan, kemudian arsip dapat dimanfaatkan oleh pengguna, setelah itu pengguna mengembalikan arsip kepada petugas layanan. Pengguna dapat mengajukan permohonan layanan reproduksi arsip kepada petugas dengan cara fotocopy atau alih media arsip. Selain berpedoman kepada Peraturan Walikota Yogyakarta Nomor 75 Tahun 2017, pelaksanaan layanan arsip statis juga diatur dalam Standar Operasional Prosedur (SOP) layanan peminjaman arsip dan konsultasi arsip. Adapun faktor-faktor yang mempengaruhi keberhasilan akses dan pemanfaatan arsip statis di Dispusip Kota Yogyakarta adalah terkait arsiparis bagian layanan dan sarana dan prasarana yang tersedia untuk memudahkan dan memberikan kenyamanan kepada pengguna dalam mengakses dan memanfaatkan arsip statis sesuai dengan kebutuhan.

\section{DAFTAR PUSTAKA}

Bettington, Jackie. (ed). 2008. Keeping Archives. Canberra: Australian Society of Archivist

Bungin, Burhan, 2011. Penelitian Kualitatif : Komunikasi, Ekonomi, Kebijakan Publik dan Ilmu Sosial Lainnya. Jakarta: Prenada Media Group

Duranti, Luciana \& Franks, Patricia C. 2017. Encyclopedia of Archival Science. London: Rowman \& Littlefield

Holbert, E Sue. 1977. Archives \& Manuscripts : Reference \& Access. Chicago: Society of American Archivists 
Moleong, Lexy J. 2014. Metodologi Penelitian Kualitatif Edisi Revisi. Bandung: Remaja Rosdakarya

Pugh, Mary Jo. 1992. Providing Reference Service For Archives and Manuscripts. Chicago: Society of American Archivists

Schellenberg, T.R. 1996. Modern Archives: Principles and Techniques. Chicago: The Soeciety of American Archivists

Semiawan, Conny R. 2010. Metode Penelitian Kualitatif : Jenis, Karakteristik dan Keunggulannya. Jakarta : PT Gramedia Widiasarana Indonesia

Ulum, M Chazienul. 2018. Public Service : Tinjauan Teoritis dan Isu-isu Strategis Pelayanan Publik. Malang : UB Press

Lampiran Peraturan Kepala Arsip Nasional Republik Indonesia Nomor 28 Tahun 2011 Tentang Pedoman Akses dan Layanan Arsip Statis

Peraturan Walikota Yogyakarta Nomor 75 Tahun 2017 tentang Pedoman Akses dan Layanan Arsip Statis

Peraturan Walikota Yogyakarta Nomor 86 Tahun 2016 Tentang Susunan Organisasi, Kedudukan, Fungsi dan Tugas, Tata Kerja Dinas Perpustakaan dan Kearsipan Daerah Kota Yogyakarta

Undang Undang Nomor 25 Tahun 2009 Tentang Pelayanan Publik

Undang Undang Republik Indonesia Nomor 43 Tahun 2009 Tentang Kearsipan

Peraturan Daerah Kota Yogyakarta Nomor 5 Tahun 2016 tentang Pembentukan dan Susunan Perangkat Daerah Kota Yogyakarta

International Council on Archives. 2000. General International Standar for Archival Description $(\operatorname{ISAD}(G))$. Canada: International Council on Archives

Committee on Best Practices and Standards Working Group on Acccess. 2012. Principles of Access to Archives. France: International Council on Archives 